\title{
PENDEKATAN KONTEKSTUAL (CTL) DAN IMPLIKASINYA DALAM PEMBELAJARAN MATEMATIKA
}

\author{
Oleh: Isra Nurmai Yenti*
}

\begin{abstract}
Contextual teaching and learning (CTL) is one of approach that able to increase learning teaching quality. This approach can be applied to all academic material not only social but also science. The characteristic of this approach is the student directly gets the experience in learning process, so that learning is meaningfull. For mathematic, students is hoped to get knowledge by construct it, not to transfer it from another person.
\end{abstract}

Kata Kunci: pendekatan kontekstual, implikasi, pembelajaran matematika

\section{PENDAHULUAN}

$\mathrm{M}$ atematika adalah ilmu dasar pengetahuan. Ini berarti matematika dipakai dalam bidang ilmu lainnya. Sebagai ilmu dasar, matematika harus dikuasai dan dipahami untuk dapat diterapkan pada ilmu-ilmu lain. Jika tidak, maka ilmu-ilmu lain juga sulit dipahami dan dimengerti.

Pentingnya mempelajari matematika tidak menjamin siswa senang mempelajarinya, bahkan mereka menganggap matematika sebagai pelajaran yang sulit dan menakutkan. Ketakutan itu berawal dari pendekatan dalam pengajaran matematika yang terkesan kaku dan dogmatis (Sutan, 2003:3). Selain itu paradigma mengajar yang dipraktekkan dalam pembelajaran matematika di sekolah, tidak memberikan kesempatan pada siswa untuk mengembangkan ideide kreatif, kemampuan berpikir strategis dan menemukan alternatif pemecahan masalah, tetapi mereka menjadi sangat tergantung pada guru, tidak terbiasa melihat alternatif lain yang mungkin dapat dipakai menyelesaikan suatu masalah secara efektif dan efisien (Marpaung dalam Muliyardi, 2003:2).

Salah satu upaya yang dapat dilakukan untuk meningkatkan kualitas pembelajaran matematika adalah melalui penerapan pendekatan kontekstual (Contextual Teaching and Learning/CTL). Dalam pembelajaran yang menggunakan pendekatan kontekstual siswa memperoleh pengetahuan dengan mengalami sendiri apa yang dipelajarinya.

Untuk itu, dalam pembahasan ini penulis akan memaparkan tentang pendekatan kontekstual dan implikasinya dalam pembelajaran matematika.

\section{PENDEKATAN KONTEKSTUAL (CTL)}

\section{Latar Belakang Lahirnya CTL}

Ada dua teori yang melatarbelakangi lahirnya CTL, yaitu teori progresivisme John Dewey dan teori kognitif. Menurut Nurhadi (2003:8) po-

* Penulis adalah Asisten Ahli dalam Mata Kuliah Kalkulus STAIN Batusangkar 
kok-pokok pandangan progesivisme antara lain:

a. Siswa belajar dengan baik apabila mereka secara aktif dapat mengkonstruksi sendiri pemahaman mereka tentang apa yang diajarkan oleh guru.

b. Anak harus bebas agar bisa berkembang wajar.

c. Penumbuhan minat melalui pengalaman langsung untuk merangsang belajar.

d. Guru sebagai pembimbing dan peneliti.

e. Harus ada kerjasama antara sekolah dan masyarakat.

f. Sekolah progresif harus merupakan laboratorium untuk melakukan eksperimen.

Teori kognitif menegaskan bahwa siswa akan belajar dengan baik apabila mereka terlibat secara aktif dalam segala kegiatan di kelas dan berkesempatan untuk menemukan sendiri. Hasil belajar yang diperoleh oleh siswa dapat berupa apa yang mereka ketahui dan apa yang yang dapat mereka lakukan.

Berpijak pada kedua teori tersebut, pandangan konstruktivisme berkembang. Melalui landasan pandangan konstruktivisme, CTL dijadikan sebagai alternatif strategi belajar yang baru.

\section{Pengertian Pendekatan Kontekstual (CTL)}

Johnson (2002:25) merumuskan pengertian CTL sebagai berikut:

"The CTL system is an educational process that aims to help students see meaning in the academic material they are studying by connecting academic subjects with the context of their daily lives, that is, with the context of their personal, social, and cultural circumstances. To achieve this aims, the system encompasses the following eight components: making meaningful connections, doing significant work, self-regu- lated leraning, collaborating, critical and creative thinking, nurturing the individual, reaching high standards, using authentic assessment."

Menurut Departemen Pendidikan Nasional (2003:5) menyatakan: "Pendekatan kontekstual (Contextual Teaching and Learning/CTL) adalah konsep belajar yang membantu guru mengaitkan antara materi yang diajarkannya dengan situasi dunia nyata siswa dan mendorong siswa membuat hubungan antara pengetahuan yang dimilikinya dengan penerapannya dalam kehidupan mereka sehari-hari, dengan melibatkan tujuh komponen utama pembelajaran efektif, yakni: konstruktivisme (Constructivism), bertanya (Questioning), menemukan (Inquiri), masyarakat belajar (Learning Community), pemodelan (Modeling), refleksi (reflection) dan penilaian sebenarnya (Authentic Assessment)."

Jadi, pendekatan kontekstual adalah konsep belajar yang mengaitkan antara materi pelajaran dengan aplikasinya dalam kehidupan sehari-hari. Siswa dituntut menemukan dan mengembangkan pengetahuan dan keterampilan baru sesuai dengan pengetahuan yang mereka miliki. Dengan demikian, siswa akan lebih memahami dan lebih memaknai pengetahuannya itu.

\section{Komponen-Komponen CTL}

CTL terdiri atas tujuh komponen utama yaitu, konstruktivisme (Constructivism), bertanya (Questioning), menemukan (Inquiri), masyarakat belajar (Learning Community), pemodelan (Modeling), refleksi (reflection) dan penilaian sebenarnya (Authentic Assessment). Berikut jabaran masing-masing komponen.

1) Konstruktivisme.

Konstruktivisme adalah salah satu aliran filsafat pengetahuan yang menekankan bahwa pengetahuan kita merupakan hasil konstruksi (bentukan) kita 
sendiri (von Glasersfeld dalam Bettencourt, 1989). Komponen ini merupakan landasan berpikir CTL yaitu bahwa pengetahuan dibangun oleh manusia sedikit demi sedikit yang hasilnya diperluas melalui kontek yang terbatas.

Dalam pandangan ini, strategi memperoleh lebih diutamakan dibandingkan seberapa banyak siswa memperoleh dan mengingat pengetahuan. Esensi dari teori konstruktivis adalah ide bahwa siswa harus menemukan dan mentransformasikan suatu informasi kompleks ke situasi lain dan apabila dikehendaki, informasi itu menjadi milik mereka sendiri. Selain itu, siswa harus mengkonstruksi pengetahuan tersebut dan memberi makna melalui pengalaman nyata.

\section{2) Bertanya}

Bertanya adalah suatu strategi yang digunakan secara aktif oleh siswa untuk menganalisis dan mengeksplorasi gagasan-gagasan (Nurhadi, 2003:45). Pada semua aktivitas belajar, bertanya dapat diterapkan: antara siswa dengan siswa, antara guru dengan siswa, antara siswa dengan guru, antara siswa dengan orang lain yang didatangkan ke kelas dan sebagainya.

\section{3) Menemukan}

Menemukan adalah salah satu cara dalam mendapatkan sesuatu. Menemukan merupakan bagian inti dari kegiatan pembelajaran menggunakan CTL. Guru harus selalu merancang kegiatan yang merujuk pada kegiatan menemukan. Ada beberapa langkah yang harus dilakukan untuk kegiatan menemukan, yaitu: merumuskan masalah, mengamati atau melakukan observasi, menganalisis dan menyajikan hasil (berupa tulisan, gambar, laporan, bagan, tabel dan karya lainnya) dan mengkomunikasikan (pada pembaca, teman sekelas, guru atau yang lainnya).

4) Masyarakat belajar
Masyarakat belajar adalah kegiatan belajar yang terjadi melalui kerjasama dengan orang lain. Masyarakat belajar bisa terjadi apabila ada proses komunikasi dua arah dan tidak ada pihak yang dominan dalam komunikasi tersebut. Prakteknya dalam pembelajaran terwujud dalam bentuk kelompok kecil, kelompok besar, mendatangkan ahli ke kelas, bekerja dengan kelas sederajat, bekerja kelompok dengan kelas di atasnya, bekerja dengan masyarakat dan sebagainya.

\section{5) Pemodelan}

Model adalah contoh yang dapat ditiru. Dalam CTL, guru bukan satusatunya model. Model dapat dirancang dengan melibatkan siswa. Model juga dapat didatangkan dari luar.

6) Refleksi

Refleksi merupakan cara berpikir tentang apa yang baru dipelajari atau berpikir ke belakang tentang hal-hal yang telah dilakukan pada masa lalu. Dengan metoda ini, siswa akan mampu berpikir ulang dan menganalisa ilmu pengetahuan yang baru didapatnya.

7) Penilaian yang sebenarnya (Authentic Assessment)

Assessment adalah proses pengumpulan berbagai data yang bisa memberikan gambaran perkembangan siswa. Dengan cara ini, guru dapat memastikan bahwa siswa mengalami proses pembelajaran yang benar. Jadi, inti dari penilaian yang sebenarnya adalah "Apakah siswa telah belajar" bukan apa yang telah diketahui siswa. Siswa tidak hanya dinilai kemampuannya dari ulangan saja, namun penilaian dilakukan dengan berbagai cara, misalnya PR, kuis, karya siswa, presentasi atau penampilan siswa, laporan dan lain-lain. Ott (1994:3) mengemukakan bahwa: Alternative assessment techniques consists of observing students working in class, asking questions, and listening to their 
answers. They involve student presentations, extended projects, and performance tasks. The creation of portfolios and written journals that show and describe student's work are very useful techniques. Other less frequently used but viable techniques are the use of interviews, conferences, and studentconstructed tests.

Menurut Newmann \& Wehlage (1993) dalam Johnson (2002:166) keuntungan penilaian autentik bagi siswa adalah:

- Fully reveal how well they understand academic material.

- Reveal and strengthen their command of SCANS competencies such as gathering information, using resources, handling technology, and thinking systematically.

- Connect learning with their own experience, their own world, and the larger community.

- Sharpen higher order thinking skills as they analyze, synthesize, identify problems, create solutions, and follow cause-effect connections.

- Accept responsibility and make choices.

- Relate to others, collaborating on tasks.

- Learn to evaluate their own level of performance.

\section{IMPLIKASI CTL DALAM PEM- BELAJARAN MATEMATIKA}

\section{Pembelajaran Matematika}

Pembelajaran merupakan suatu upaya menciptakan kondisi yang memungkinkan siswa dapat belajar. Pembelajaran lebih menekankan pada bagaimana upaya guru mendorong atau menfasilitasi siswa belajar, bukan pada apa yang dipelajari siswa. Istilah pembelajaran lebih menggambarkan bahwa siswa lebih banyak berperan dalam mengkonstruksikan pengetahuan bagi dirinya dan bahwa pengetahuan itu bukan hasil proses transformasi dari guru (Muliyardi, 2002:3).

Dalam hubungannya dengan pelajaran matematika, Nikson (1992) dalam Muliyardi (2002:3) mengemukakan bahwa pembelajaran matematika adalah upaya membantu siswa untuk mengkonstruksi konsep-konsep atau prinsipprinsip matematika dengan kemampuannya sendiri melalui proses internalisasi sehingga konsep atau prinsip itu terbangun kembali. Dengan demikian, pada pembelajaran matematika siswa dibiasakan untuk memperoleh pemahaman melalui pengalaman tentang sifat-sifat yang dimiliki dan tidak dimiliki dari suatu objek. Dengan pengamatan terhadap contoh-contoh dan bukan contoh diharapkan siswa mampu menangkap pengertian suatu konsep.

\section{Penerapan Pendekatan Kontekstual di Kelas}

Pendekatan kontekstual dapat dilaksanakan dengan berbagai macam strategi, yaitu: pengajaran berbasis masalah, pengajaran kooperatif, pengajaran berbasis inkuiri, pengajaran berbasis proyek/tugas, pengajaran berbasis kerja dan pengajaran berbasis jasa layanan (Nurhadi, 2003:55). Berikut penjelasan tentang strategi pengajaran berbasis masalah dan pengajaran kooperatif yang dapat digunakan dalam pembelajaran matematika.

\section{Pengajaran Berbasis Masalah}

Pengajaran berbasis masalah (Problem-Based Learning) adalah suatu pendekatan pengajaran yang menggunakan masalah dunia nyata sebagai konteks bagi siswa untuk belajar tentang cara berpikir kritis dan keterampilan pemecahan masalah, serta untuk memperoleh pengetahuan dan konsep yang esensial dari materi pelajaran (Nurhadi, 2003:55). 
Ciri-ciri pengajaran berbasis masalah dalam Ibrahim (2000a:5-7) adalah:

1) Pengajuan pertanyaan atau masalah. Ronis (2001:58) menyatakan “...the problem may be voiced as a question, a case study, an example, a charge, a hyphothesis, or a situation. The problem should be realistic so that students can relate to its context...".

2) Berfokus pada keterkaitan antar disiplin. Masalah yang telah dipilih dalam diselesaikan dari berbagai mata pelajaran.

3) Penyelidikan autentik

4) Menghasilkan produk/karya dan memamerkannya. Produknya dapat berupa laporan, model fisik, video atau program komputer.

Pola keseluruhan dan alur kegiatan pada pengajaran berbasis masalah dapat dilihat pada tabel di bawah ini.

Tabel 1: Sintak Pengajaran Berbasis Masalah

\begin{tabular}{|c|c|}
\hline & Tingkah Laku Guru \\
\hline $\begin{array}{l}\text { Tahap-1 } \\
\text { Orientasi } \\
\text { siswa } \\
\text { kepada } \\
\text { masalah }\end{array}$ & $\begin{array}{l}\text { Guru menjelaskan tujuan pem- } \\
\text { belajaran, menjelaskan logistik } \\
\text { yang dibutuhkan, memotivasi } \\
\text { siswa terlibat pada aktivitas } \\
\text { pemecahan masalah yang di- } \\
\text { pilihnya. }\end{array}$ \\
\hline $\begin{array}{l}\text { Tahap-2 } \\
\text { Mengorgani } \\
\text { sasi siswa } \\
\text { untuk } \\
\text { belajar }\end{array}$ & $\begin{array}{l}\text { Guru membantu siswa men- } \\
\text { definisikan dan mengorgani- } \\
\text { sasikan tugas belajar yang } \\
\text { berhubungan dengan masalah } \\
\text { tersebut. }\end{array}$ \\
\hline $\begin{array}{l}\text { Tah } \\
\text { Men } \\
\text { bing } \\
\text { lidik } \\
\text { vidu } \\
\text { kelo }\end{array}$ & $\begin{array}{l}\text { mengumpulkan infor } \\
\text { yang sesuai, melaksan } \\
\text { eksperimen untuk menda } \\
\text { kan penjelasan dan pemec }\end{array}$ \\
\hline $\begin{array}{l}\text { hap-4 } \\
\text { engemban } \\
\text { an dan } \\
\text { nyajikan }\end{array}$ & $\begin{array}{l}\text { Guru membantu siswa dalam } \\
\text { merencanakan dan menyiap- } \\
\text { kan karya yang sesuai seperti } \\
\text { laporan, video dan model dan } \\
\text { membantu mereka untuk ber- } \\
\text { bagi tugas dengan temannya. }\end{array}$ \\
\hline $\begin{array}{l}\text { Tahap-5 } \\
\text { Mengana } \\
\text { lisis dan } \\
\text { mengevalu }\end{array}$ & $\begin{array}{l}\text { Guru membantu siswa untuk } \\
\text { melakukan refleksi atau eva- } \\
\text { luasi terhadap penyelidikan } \\
\text { mereka dan proses yang }\end{array}$ \\
\hline
\end{tabular}

\begin{tabular}{|l|l|}
\hline $\begin{array}{l}\text { si proses } \\
\text { pemecahan } \\
\text { masalah }\end{array}$ & mereka gunakan. \\
\hline
\end{tabular}

Sumber: Ibrahim, 2000a:13

\section{Pengajaran Kooperatif}

Pengajaran kooperatif merupakan strategi pembelajaran yang mengutamakan adanya kerjasama antara siswa dalam kelompok untuk mencapai tujuan pembelajaran (Johnson \& Johnson dalam Ismail, 2003:18). Para siswa dibagi dalam kelompok-kelompok kecil untuk secara bersama menyelesaikan atau mempelajari tugas yang diberikan kepada kelompoknya. Dalam pengajaran kooperatif ini, guru bertindak sebagai fasilitator.

Pengelompokkan siswa dalam pengajaran kooperatif merupakan pengelompokkan yang heterogenitas (bermacam ragam). Pengelompokkan ini dapat dibentuk dengan memperhatikan keanekaragaman gender, latar belakang sosio-ekonomi, etnik dan kemampuan akademis (Lie, 2002:40).

Langkah-langkah pembelajaran menggunakan pengajaran kooperatif adalah:

Tabel 2: Sintak Pengajaran Kooperatif

\begin{tabular}{|l|l|}
\hline \multicolumn{1}{|c|}{ Tahap } & \multicolumn{1}{c|}{ Tingkah Laku Guru } \\
\hline $\begin{array}{l}\text { Tahap-1 } \\
\text { Menyampai } \\
\text { kan tujuan dan } \\
\text { memotivasi } \\
\text { siswa }\end{array}$ & $\begin{array}{l}\text { Guru menyampaikan semua } \\
\text { tujuan pelajaran yang ingin } \\
\text { dicapai pada pelajaran ter- } \\
\text { sebut dan memotivasi siswa } \\
\text { belajar. }\end{array}$ \\
\hline $\begin{array}{l}\text { Tahap-2 } \\
\text { Menyajikan } \\
\text { informasi }\end{array}$ & $\begin{array}{l}\text { Guru menyajikan informasi } \\
\text { kepada siswa dengan jalan } \\
\text { demonstrasi atau lewat ba- } \\
\text { han bacaan. }\end{array}$ \\
\hline $\begin{array}{l}\text { Tahap-3 } \\
\text { Mengorganisa } \\
\text { sikan siswa ke } \\
\text { dalam kelom- } \\
\text { pok-kelompok } \\
\text { belajar }\end{array}$ & $\begin{array}{l}\text { Guru menjelaskan kepada } \\
\text { siswa bagaimana caranya } \\
\text { membentuk kelompok be- } \\
\text { lajar dan membantu setiap } \\
\text { kelompok agar melakukan } \\
\text { transisi secara efisien. }\end{array}$ \\
\hline $\begin{array}{l}\text { Tahap-4 } \\
\text { Membimbing } \\
\text { kelompok be- } \\
\text { kerja dan bela- } \\
\text { jar }\end{array}$ & $\begin{array}{l}\text { Guru membimbing kelom- } \\
\text { pok-kelompok belajar pada } \\
\text { saat mereka mengerjakan } \\
\text { tugas. }\end{array}$ \\
\hline
\end{tabular}




\begin{tabular}{|l|l|}
\hline $\begin{array}{l}\text { Tahap-5 } \\
\text { Evaluasi }\end{array}$ & $\begin{array}{l}\text { Guru mengevaluasi hasil } \\
\text { belajar tentang materi yang } \\
\text { telah dipelajari atau masing- } \\
\text { masing kelompok mem- } \\
\text { presentasikan hasil kerjanya }\end{array}$ \\
\hline $\begin{array}{l}\text { Tahap-6 } \\
\text { Memberikan } \\
\text { penghargaan }\end{array}$ & $\begin{array}{l}\text { Guru mencari cara-cara } \\
\text { untuk menghargai baik } \\
\text { upaya maupun hasil belajar } \\
\text { individu dan kelompok }\end{array}$ \\
\hline
\end{tabular}

Sumber: Ibrahim, 2000b:10

Pelaksanaan pengajaran kooperatif dalam proses pembelajaran dapat dilakukan dengan menerapkan salah satu tipe. Tipe-tipe pembelajaran kooperatif tersebut adalah Students Teams Achievement Division (STAD), Teams Games Tournamens (TGT), Cooperative Integrated Reading and Composition (CIRC), Group Investigation (GI), Jigsaw, ThinkPair-Share, Numbered Head Together, Learning Together (belajar bersama), kancing gemerincing, dua tinggal dua tamu dan lain-lain.

\section{Contoh Penerapan Pendekatan Kon- tekstual dalam Pembelajaran Mate- matika}

Kompetensi Dasar (KD): "Menyelesaikan model matematika dari masalah program linear dan penafsirannya". KD ini dapat dilakukan dengan dua cara yaitu dengan metode uji titik pojok dan garis selidik. Penyelesaian model matematika dari masalah program linear dengan garis selidik menggunakan pengajaran berbasis masalah, adalah sebagai berikut:

- Tahap 1: mengorientasikan siswa pada masalah

* Guru mengajukan masalah yang ada di LKS dan meminta siswa mempelajari masalah tersebut.

* Guru memotivasi siswa terlihat pada aktifitas pemecahan masalah yang ada di LKS.

- Tahap 2: mengorganisasi siswa untuk belajar

* Guru meminta siswa mengemukakan ide kelompoknya sendiri tentang cara menyelesaikan masalah tersebut.

- Tahap 3: membimbing penyelidikan individual maupun kelompok

* Guru membimbing/mendorong untuk mencari persamaan garis yang sederhana, menemukan penjelasan masalah dan cara penentuan nilai optimum.

* Guru mendorong dialog atau diskusi antar siswa dalam kelompoknya untuk menentukan persamaan garis yang sederhana, menggambar persamaan garis dan penentuan nilai optimum.

- Tahap 4: mengembangkan dan menyajikan hasil kerja

* Guru memilih dua kelompok secara acak untuk mempresentasikan hasil pemecahan masalah yang masing-masing diwakili oleh salah seorang anggota kelompok, sedangkan kelompok yang lain menanggapi.

- Tahap 5: menganalisis dan mengevaluasi proses pemecahan masalah

* Guru membantu siswa mengkaji ulang proses/hasil pemecahan masalah

\section{LEMBARAN KERJA SISWA}

Nama

Kelompok: Tanggal

Petunjuk: Waktu yang disediakan adalah 30 menit

\section{Proyek 1: Memahami pengertian garis selidik}

Diketahui suatu persamaan garis $2 \mathrm{x}+\mathrm{y}=\mathrm{k}(\mathrm{k} \in \boldsymbol{R})$. Titik potong garis $2 \mathrm{x}$ $+\mathrm{y}=\mathrm{k}$ dengan sumbu koordinat dapat ditentukan sebagai berikut:

Titik potong dengan sumbu $\mathrm{x}$ didapat dari $\mathrm{y}=0$

$$
2 \mathrm{x}+0=\mathrm{k} \Leftrightarrow \mathrm{x}=\ldots
$$



adalah ...

Jadi titik potong dengan sumbu $\mathrm{x}$

Titik potong dengan sumbu $\mathrm{y}$ didapat dari $\mathrm{x}=0$

$$
2(0)+\mathrm{y}=\mathrm{k} \Leftrightarrow \mathrm{y}=\ldots
$$

Jadi titik potong dengan sumbu y adalah ...Grafik garis $2 \mathrm{x}+\mathrm{y}=\mathrm{k}$ dapat dilukis dengan menghubungkan titik potong garis terhadap sumbu $\mathrm{x}$ dan titik potong garis terhadap sumbu $\mathrm{y}$.

1. Gambarlah grafik garis $2 \mathrm{x}+\mathrm{y}=\mathrm{k}$ untuk nilai $\mathrm{k}=0, \mathrm{k}=1, \mathrm{k}=2, \mathrm{k}=3$, $\mathrm{k}=4, \mathrm{k}=5, \mathrm{k}=6, \mathrm{k}=7, \mathrm{k}=8, \mathrm{k}=9$ dan $\mathrm{k}=10$ dengan skala $1 \mathrm{~cm}$ untuk 1 satuan.

2. Berdasarkan gambar di atas, apa yang dimaksud dengan garis selidik?

\section{Proyek 2: Menentukan nilai optimum suatu fungsi objektif}

Diketahui suatu sistem pertidaksamaaan linear $\mathrm{x} \geq 0, \mathrm{y} \geq 0, \mathrm{x}+\mathrm{y} \leq 5$, dan $\mathrm{x}+2 \mathrm{y} \leq 6$ dengan $\mathrm{x}$ dan $\mathrm{y} \in \boldsymbol{R}$. Bentuk objektifnya merupakan persamaan garis selidik dari proyek 1 yang berbentuk $2 \mathrm{x}+\mathrm{y}$.

1. Tunjukkan daerah himpunan penyelesaian sistem pertidaksamaan di atas pada bidang Cartesius.

2. Dengan menggunakan garis selidik, tentukan nilai optimum (maksimum dan minimum) dari bentuk objektif $2 \mathrm{x}$ $+\mathrm{y}$, dengan ketentuan:

\section{DAFTAR RUJUKAN}

Bettencourt, A. 1989. What is Constructivism and Why are They All Talking about It? Michigan State University,

Departemen Pendidikan Nasional. 2003. Pendekatan Kontekstual (Contextual Teaching and Learning/ CTL), Jakarta a. Untuk garis $2 \mathrm{x}+\mathrm{y}=\mathrm{k}_{1}$ yang terletak paling jauh dari titik pangkal dan melewati titik A $\left(\mathrm{x}_{1}, \mathrm{y}_{1}\right)$ (titik $\mathrm{A}\left(\mathrm{x}_{1}, \mathrm{y}_{1}\right)$ terletak pada daerah himpunan penyelesaian) maka $\mathrm{A}\left(\mathrm{x}_{1}, \mathrm{y}_{1}\right)$ merupakan titik yang menjadikan bentuk $2 \mathrm{x}+\mathrm{y}$ maksimum. Nilai maksimum bentuk objektif itu sama dengan $2 \mathrm{x}_{1}+$ $\mathrm{y}_{1}=\mathrm{k}_{1}$.

b. Untuk garis $2 \mathrm{x}+\mathrm{y}=\mathrm{k}_{2}$ yang terletak paling dekat dari titik pangkal dan melewati titik $\mathrm{B}\left(\mathrm{x}_{2}, \mathrm{y}_{2}\right)$ (titik $\mathrm{B}\left(\mathrm{x}_{2}, \mathrm{y}_{2}\right)$ terletak pada daerah himpunan penyelesaian) maka $\mathrm{B}\left(\mathrm{x}_{2}, \mathrm{y}_{2}\right)$ merupakan titik yang menjadikan bentuk $2 \mathrm{x}+\mathrm{y}$ minimum. Nilai minimum bentuk objektif itu sama dengan $2 \mathrm{x}_{2}+\mathrm{y}_{2}=\mathrm{k}_{2}$.

\section{KESIMPULAN}

Pendekatan kontekstual (CTL) dapat meningkatkan kualitas pembelajaran matematika. Pada pendekatan kontekstual (CTL), siswa mengalami langsung materi atau konsep yang diajarkan. Materi pelajaran ditemukan sendiri oleh siswa, bukan hasil pemberian dari orang lain. Kelas bukanlah tempat untuk mencatat atau menerima informasi dari guru, akan tetapi kelas digunakan untuk saling membelajarkan.

Ibrahim, Muslimin. 2000a. Pengajaran Berdasarkan Masalah, Surabaya: UNESA-University Press, 2000b. Pembelajaran Kooperatif, Surabaya: UNESA

Ismail. 2003. Model-Model Pembelajaran, Jakarta: Direktorat Pendidikan Lanjutan Pertama Dirjen Pendidikan Dasar dan Menengah Depdiknas 
Johnson, Elaine B. 2002. Contextual Teaching and Learning: What It is and Why It's Here to Stay, California: Corwin Press Inc

Lie, Anita. 2002. Cooperative Learning Mempraktekkan Cooperative di Ruang-Ruang Kelas, Jakarta: Gramedia

Muliyardi. 2002. Strategi Pembelajaran Matematika, Padang: Jurusan Matematika FMIPA UNP . 2003. Ketika Seni Bercumbu dengan Matematika, Makalah disajikan pada Seminar Nasional Difusi dan Inovasi Pembelajaran Matematika di Universitas Negeri Padang Tanggal 6 September
Nurhadi dan Senduk. 2003. Agus Gerrad, Pembelajaran Kontekstual (Contextual Teaching and Learning/CTL) dan Penerapannya dalam $K B K$, Malang: Universitas Negeri Malang

Ott, Jack. 1994. Alternative Assessment in the Mathematics Classroom, New York: Glencoe/McGraw-Hill

Ronis, Diane. 2001. Problem Based Learning for Math and Science: Integrating Inquiry and the Internet, America: Skylight Training and Publishing Inc

Sutan, Firmanawaty. 2003. Mahir Matematika melalui Permainan, Jakarta: Puspa Swara 